\title{
インドネシア・バンダアチェにおける2004年インド洋津波後の 生活再建過程の構造化 \\ STRUCTURE OF RECOVERY PROCESS IN BANDA ACEH, INDONESIA AFTER THE 2004 INDIAN OCEAN TSUNAMI
}

\author{
仲里英晃*, 村尾修**, 杉安和也* \\ Hideaki NAKAZATO, Osamu MURAO and Kazuya SUGIYASU
}

\begin{abstract}
Housing reconstruction projects supported with foreign agencies such as JICA and USAID are under process in Banda Aceh, Indonesia, the most damaged area due to the 2004 Indian Ocean Tsunami. As of March 2008, there are still some problems with regard to city and village planning in the post recovery process from the viewpoint of disaster management. The authors conducted a field survey in March 2008 to understand the recovery conditions, and had interview to JICA, BRR, and the victims about livelihood condition at new resettlement sites. This paper demonstrates the recovery process of affected people, and clarifies the problems of the reconstruction and rehabilitation project managed by BRR using structural chart of post-disaster recovery process.
\end{abstract}

Keywords : the 2004 Indian Ocean Tsunami, Banda Aceh, recovery process, permanent house, livelihood problems 2004 年インド洋津波，バンダアチェ市，再建過程，恒久住宅，居住環境問題

\section{1. はじめに}

2004 年 12 月にインド洋沿岸諸国を襲った津波により，インドネ シアではスマトラ島北部のバンダアチェ市を中心に死亡者数が 167,000 人，住宅を失った被災者が 50 万人以上にのぼる未曾有の被 害となった。そして, 最大の被災地であったアチェ州では 80,000か ら 110,000 戸の住宅再建が必要とされた. また, バンダアチェ市を 中心におよそ $3,000 \mathrm{~km}$ の道路が通行不能に陥ったほか, 各地域で幹 線道路に架かる橋梁（約 120）を含め, 1,500 以上の橋梁が壊れるな ど各種インフラの被害も甚大なものであった ${ }^{1)}$.

被災後，政府は被災地で復興全般の事業を統括・遂行する機関と してアチェ・ニアス復興庁 (Badan Rehabilitasi dan Redonstruksi NAD-Nias，以下 BRR）を設置し，各国政府および海外 NGO からの 支援をもとに被荻地の再建に取り組んだ。現在, 被苂から 3 年以上 が経過したものの，再建プロセスにおいて被災地全体の復興マスタ ープラン作成を担当した国際協力機構（以下 JICA）と地域ごとのヴ イレッジプランを作成した米国国際開発庁 (United States Agency for International Development，以下 USAID）との間で異なるアプローチ がとられたため，事業の遅れと混乱が生じている.

復興住宅に関する研究は多くの蓄積があるが, 2004 年スマトラ沖 地震に関するものとしてはまず, 岡崎, 楢府 ${ }^{2}$ によるインドネシア,
アチェにおける住宅再建の実態に関する研究があげられる。このな かでは，主に再建された住宅の質に着目した上で，バンダアチェ市 の住宅事情に即した一定以上の質をもった復興住宅建設実現に向け た提言を行っている。また，津波後の復興過程に着目した既往研究 として, 前田ら ${ }^{3)}$ はスマトラ沖地震津波被災地であるスリランカ南 西沿岸居住地におけるその実態と問題点に関して考察を行っている そして, 同津波で被害を受けたタイの復興過程に関する研究として 佐藤 ${ }^{4)}$ の研究が挙げられる。この研究では，復興に関わった政府機 関, 外国機関, NGO などの主体ごとに復興事業における役割を整理 し事業進行過程における課題を指摘している.さらに，山本・牧 ${ }^{5)}$ はバンダアチェ市における復興住宅の初期供給プロセスに着目し, 供給側，被災者側の両面から供給プロセスを整理している.

被災地の地域性や文化の違いにより多様となる復興過程を構造化 寸る試みとしては, 池田・中林 ${ }^{6}$ の研究が挙げられる。この研究で は, 1999 年のトルコ・コジャエリ地震, 台湾の集集地震, そして 1995 年の兵庫県南部地震の各被災地の復興過程を比較し, 各国における 恒久住宅の復興過程と支援策の違いを明らかにしている。また， $\mathrm{Murao}^{7)}$ は 1999 年台湾集集地震の被災地の復興プロセスに着目し, 復興過程に関するリサーチクエスチョンを抽出し, その構造化を試 みている.
* 筑波大学大学院システム情報丁学研究科 大学院生・学士 (社会工学)

** 筑波大学大学院システム情報工学研究科 准教授・博士 (工学)
Graduate School Student, Graduate School of Systems and Information Engineering, University of Tsukuba, Bachelor of Policy and Planning Sciences

Assoc. Prof., Graduate School of Systems and Information Engineering, University of Tsukuba, Dr. Eng. 
大災害時には住民の集団移転や，再建住宅の居住性など時間の経 過にともない表層化してくる問題も多い。そこで筆者らは長期的な 視点に基づき，スリランカやタイ，インドネシアといった津波被災 地の復興過程に関する調查, 研究を行っておりバンダアチェ市に関 しても報告してきた ${ }^{8)-10)}$ ．その一環として，津波により甚大な被害 を受けたバンダアチェ市における生活再建プロセスを対象として, 2008 年 2 月 27 日から 3 月 3 日にかけて現地調查を実施した。本稿 では，復興過程を構造的に示し，復興過程における問題を明らかに することを目的とする. 具体的には, 被苂者および BRRへのインタ ビューを通して,被災から約 3 年が経過した 2008 年 2 月時点におけ る被災地の現状を整理し，再建プロセスを構造化することにより， 立場や地域の違いによる生じる再建プロセスの差異と問題点につい て考察する。

\section{2. 住宅再建事業の概要と再建状況}

\section{(1) 実施機関と再建方針}

インドネシアの復興事業はインドネシア政府国家開発庁（Badan Perencanaan dan pembangunan Nasional, 以下 BAPPENAS) が統括し, 地方レベルの事業の管轄を BAPPENAS の地方庁である地域計画局

（Badan Perencanaan Pembangunan Daerah，以下 BAPPEDA）が担当 寸ることになった。しかし，アチェ州においては，被害がはるかに 大きかったため BAPPEDA では対応しきれず，北スマトラ島での 復興事業は 2005 年 4 月頃，BAPPENAS 直轄の機関である BRRに 移蚊された。以降，BRR がアチェ州における住宅再建事業を含む 復興事業全般を統括することとなった。

\section{(2) 事業実施の流れ}

再建事業にかかる費用は大きく，オンバジット (On-budget Funds) とオフバジット (Off-budget Funds) の二つに分割される ${ }^{11}$. 前者は, 国家および地方自治体の予算，そして NGO など海外支援機関から の支援金をもとに，政府が中心となって進めるプロジェクトに充て られた。一方で後者は, NGO から BRRに提出されたコンセプトノ 一トが審查を通過した後, NGO が行うプロジェクトに充てられた ${ }^{11)}$. コンセプトノートが審査を通過しなかった場合は，申請者は計画書 を修正したうえで再提出が求められ，再審査を通過した後にプロジ エクトの実施にいたるというものであった（図 1).

バンダアチェ市全体の復興計画は，インドネシア政府から委託さ れた JICA がマスタープランを作成した。一方で，予算の問題など から住宅再建事業が遅れるなか, BRR は当初から掲げていたコミュ ニティベースの復興計画といった住宅の再建事業を促進させるため, ヴィレッジプラン作成の支援をUSAID に委託した ${ }^{12)}$.このように， 地域全体のマスタープランと，村レベルのヴィレッジプランの両方 をもとに住宅の再建が進められることとなった。そして，住宅の再 建に必要な資金は各国政府や国際機関，海外の支援団体からの支援 を元にまかなわれたが,その資金の管理および運営は BRRが担った.

\section{(3) 実施状況}

被災から 3 年以上が経過した調查時点においてもなお，BRR 主導 で被災地の住宅再建が進められている。表 1 , 図 2 は住宅の再建状 況の推移であるが，アチェ州全体で再建された恒久住宅は 2007 年

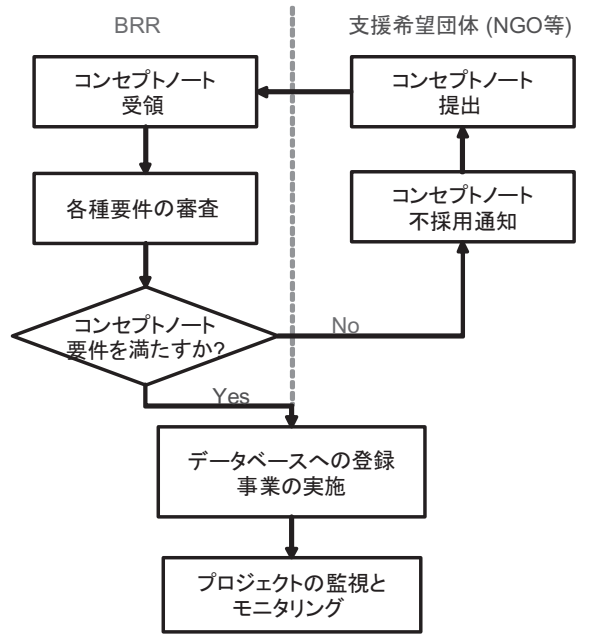

図 1 コンセプトノートの提出から事業実施までの流れ

表 1 アチェ州の住宅の再建状況（2008 年 2 月時点） ${ }^{13}$

\begin{tabular}{|c|c|c|c|c|c|c|c|c|}
\hline & 2006 & \multicolumn{6}{|c|}{2007} & 2008 \\
\hline & 12月 & 4月 & 6月 & 8月 & 10月 & 11月 & 12月 & 1月 \\
\hline 恒久住宅（累計戸数） & 57,000 & 64,971 & 84,387 & 90,861 & 102,063 & 102,063 & 104,287 & - \\
\hline 仮設住宅（累計戸数） & 15,000 & 17,159 & 17,159 & 18,424 & 19,482 & 19,482 & 19,889 & 19,889 \\
\hline 仮設住宅居住世帯数 & 14,317 & - & 10,959 & 6,267 & 5,287 & 4,149 & 3,698 & 2,229 \\
\hline
\end{tabular}

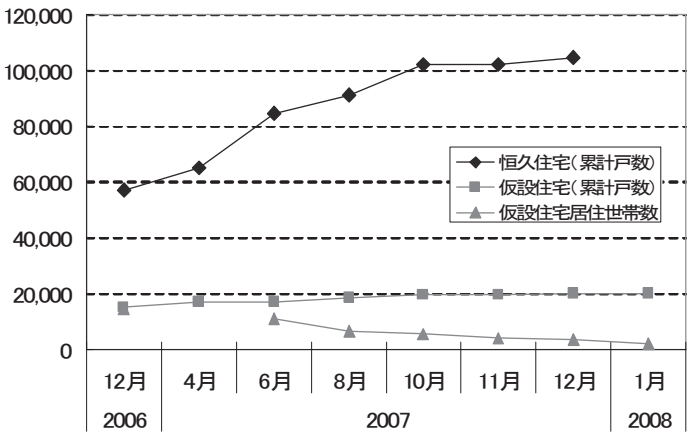

図 2 アチェ州における住宅建設戸数の推移 ${ }^{13}$

12 月時点で 104,287 戸となっている。 そして BRRによると 2008 年 1 月時点における残り建設予定戸数は 155,838 戸となっている ${ }^{13)}$. 仮設住宅に関しては, 建設戸数が 2006 年 12 月から 2008 年 1 月にか けて約 5,000 戸の増加となっている。 そして，アチェ州全体として は，仮設住宅で避難生活を続ける被災者は 2008 年 1 月時点で 2,229 世帯であり，2006 年 12 月時点の 14,317 世帯から大幅に減少してい る. その一方で, 仮設住宅の建設戸数は 2007 年 12 月まで増加して いる(図 2). 被災から 2 年が経過した後も仮設住宅の建設が続けら れていることから，地域によっては仮設住宅の建設が遅れ，被災者 の仮設住宅入居が遅れていると考えられる.

最も被害の大きかったバンダアチェ市では国連機関や赤十字社, 国内外の NGO など 121 のドナーの支援により住宅の再建が進めら れた．支援団体から BRR に提出されたコンセプトノートの総数は 2008 年 3 月現在, 1,592 にのぼる ${ }^{11)}$.

\section{3．被災地の復興状況調査}

\section{(1) 調査地の選定}

アチェ州においては前述したように数多くの支援団体が被災地に 
入り被災家屋の再建を進めている，なかでも，慈済基金は図 3 に示 すようなバンダアチェ市の内陸部に 716 戸，その他にアチェブサー ル県に 850 戸,メラボウ県に 1,100 戸の恒久住宅を建設している注1). 筆者らは被災から約 3 年が経過した 2008 年 2 月 28 日から 3 月 3 日 にかけて, 被災地でどの程度復興が進んでおり, どのような問題が あるかを把握するためにスマトラ島北部アチェ州のバンダアチェ市, アチェブサール県で現地調查を行った.

今回の調査では, まず, バンダアチェ市の再定住地を訪れ, 同住 宅地の管理主体および居住者に対して恒久住宅地の管理形態, 住宅 および施設の配置計画, 被災者の入居までの過程に関して調查を実 施した。当住宅地を調查対象地に選んだ理由としては, アチェ州の なかでも最も被害が大きかったバンダアチェ市内に建設された住宅 地であること, そして, バンダアチェ市内の広い範囲から被災者が 移転していることが挙げられる，また，慈済基金の再定住地以外に も被災地で住宅の再建が進んでいるため, 土地が掘削され大きな被 害を出したバンダアチェ市内のウレレなど，沿岸被災地においても 同様の調查を行った。

\section{(2) 慈済基金住宅地の概要}

今回調查を実施した住宅地（Komplek Perumahan Cinta kashi Tzu-Chi 1) は, バンダアチェ市の海岸線から約 $4 \mathrm{~km}$ の内陸部，パン テリエクに位置し（図 3), 図4 亿示すようなコミュニティプランに もとづき住宅地が建設された。 総住宅戸数は前述した通り, 716 戸 である．被災者の再定住地建設のために政府が土地を買い上げ，川 の流れを点線部から実線部のように変えることで用地を確保してい る。資金を援助した慈済基金は2（2）に記したように，BRR にコン セプトノートを提出し, 両者の間で行われたやりとりのなかで建設 戸数，施設配置などが決定された。敷地内には住宅（写真 1）のほ か, 幼稚園, 小学校, 中学校, そしてモスクを兼祇た集会所が配置 されている

全 716 戸のうち, 200 戸が 2005 年 8 月に完成し敷地内北東のブロ ックに第一団が入居した。 その後住宅が完成するごとに北東から南 西のブロックの順に被災者が入居し, 最終的に入居が完了したのは 2007 年 9 月である.

\section{(3) 調査方法}

事前に作成した質問表をもとに，被災場所，被災から恒久住宅に 入居するまでの経緯，被災前後の仕事の変化，住宅を建設した援助 機関・団体および，住宅地内の環境など生活する上での問題点につ いて面接形式の調查を実施した。慈済基金住宅地でのヒアリング総 数は 16 件である.また沿岸部の 4 箇所の被災地での調査では, 全体 的な状況と世帯としての状況を 1 人もしくは複数の被災者から聞き 取った。慈済基金住宅地は全部で 16 ブロックに分かれており, 調查 時には 1 ブロックから 1 件のヒアリング調查を実施した。なお，沿 岸被災地でのヒアリング調查地は，慈済基金住宅地入居者の被災以 前の居住地である.

\section{4. 住宅の再建過程}

\section{(1) 本研究における復興プロセスの定義}

災害後の復興における主体は, 都市, 地区, 家族, そして個人な

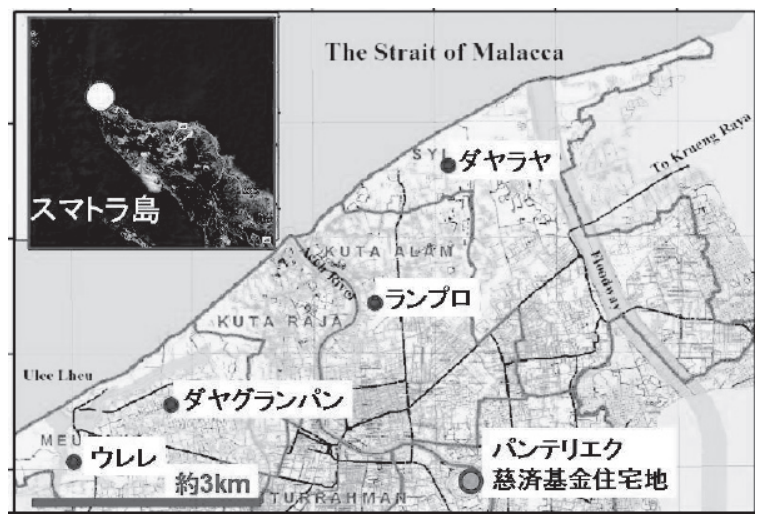

図 3 慈済基金住宅再建地の位置

引用：JICA,インドネシア国北スマトラ沖津波災害緊急復旧・復興支援プ ログラム 最終報告書（1)，より引用，加工

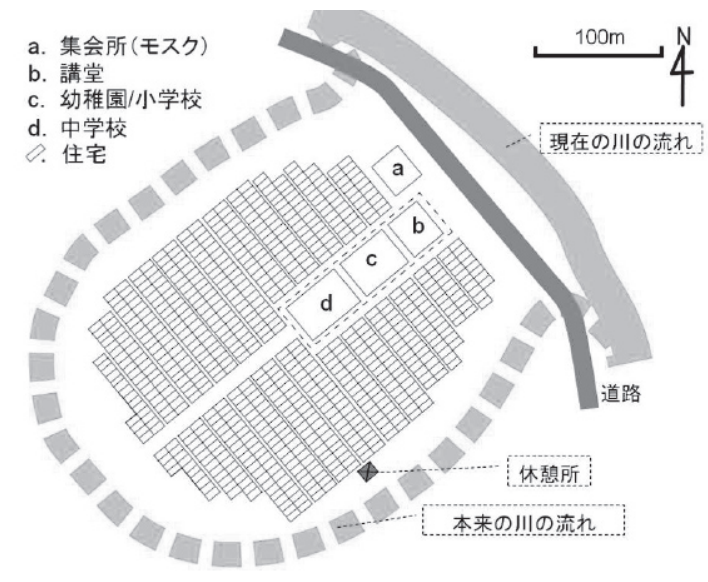

図 4 慈済基金住宅地のコミュニティプラン

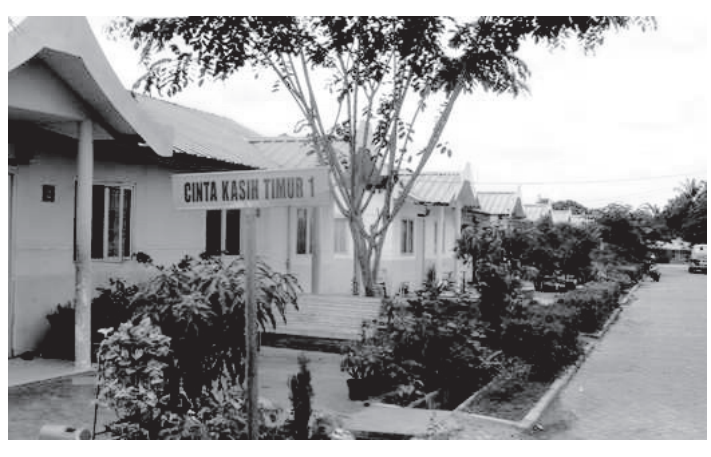

写真 1 住宅地概観

ど様々であり，主体の規模が異なることで復興の度合いを図る尺度 も異なる，本研究では，被苂家屋の再建に着目し，個人，家族単位 で被災者が生活を再建するプロセスを明らかにするために，ここで は被災後の時間の変遷を以下のように第 1 段階から第 4 段階に分け （表 2)，個々の被災者の復興プロセスについて整理し，問題点を明 らかにする。

\section{(1) 第 1 段階: 緊急避難}

被災直後から約 $1 ， 2$ ケ月の時期で公共施設，仮設テント，親戚 宅，または病院などで過ごす期間。一日一日を無事に過ごすこ とで精一杯の時期である。 


\section{(2) 第 2 段階：避難生活}

被災後 $2 ， 3$ ケ月から 1 年半ほどの時期で仮設住宅，親戚宅な ごで過ごす期間. 住宅再建に向けた準備期間として位置づけら れる。

\section{(3) 第 3 段階：住宅再建}

被災後 1 年から 3 年ほどの期間で, 避難生活から抜け出し, 生 活再建の基盤となる住宅再建を進める期間. 復興プロセスのな
かで，一定の目標時点となる.

\section{(4) 第 4 段階：生活の再建，生活基盤の確立}

時期は個人によって異なるが，早いケースで被災から 1 年，遅 いケースで 3 年ほじ経過した時点. 第 3 段階で得られた住宅に 問題が無い場合，新たな生活基盤を確保できることとなる．再 定住地では，移転に伴う生活面の変化（仕事，土地，コミュニ ティ）に対する期待と不安を抱えながらの再出発となる.

表 2 復興過程の変遷に伴う各段階

\begin{tabular}{|c|c|c|c|}
\hline & 段階の位置づけ & 被災からのおおよその時間 & 関係機関 \\
\hline 第1段階 & 緊急避難（公共施設, 病院, 親戚宅など) & 被災直後〜1,2ヶ月 & BAPPENAS, BAPPEDA \\
\hline 第2段階 & 避難生活（仮設住宅，親戚宅など） & 2,3 ケ月～1年半 * & $\begin{array}{l}\text { BRR, } \\
\text { ドナー（NGO，海外支援団体） }\end{array}$ \\
\hline 第3段階 & 住宅再建 & 1年～3年 $\%$ & $\begin{array}{l}\text { BRR, JICA, USAID, } \\
\text { ドナー (NGO, 海外支援団体) }\end{array}$ \\
\hline 第4段階 & 生活の再建, 生活基盤の確立 & 1年～* & BRR（2009年解散予定） \\
\hline
\end{tabular}

表 3 慈済基金住宅地入居者の住宅再建までの経緯および居住環境に関する問題点

\begin{tabular}{|c|c|c|c|c|c|c|c|c|}
\hline \multirow{2}{*}{ No. } & \multirow{2}{*}{\begin{tabular}{|l} 
被災場所 \\
住宅の所有形態
\end{tabular}} & \multirow{2}{*}{ 恒久住宅入居までの生活 } & \multirow{2}{*}{$\begin{array}{l}\text { 恒久住宅 } \\
\text { 入居時期 }\end{array}$} & \multirow{2}{*}{ 恒久住宅への応募方法 } & \multicolumn{2}{|r|}{ 仕事 } & \multirow{2}{*}{\begin{tabular}{|c|} 
住宅・設備に \\
関する問題 \\
\end{tabular}} & \multirow{2}{*}{ 備考 } \\
\hline & & & & & $\begin{array}{l}\text { 被災前 } \\
\end{array}$ & 被災後 & & \\
\hline 1 & \begin{tabular}{|l} 
リンケ \\
借家
\end{tabular} & 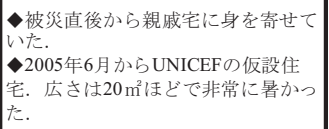 & $2007 / 09$ & 慈済基金に申し込んだ. & |警察官 & 警察官 & 特に無し & 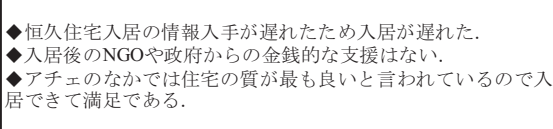 \\
\hline 2 & \begin{tabular}{|l} 
ジュリンケ \\
借家
\end{tabular} & \begin{tabular}{|l}
-恒久住宅入居（2007/09）まで親戚 \\
宅で過ごす.
\end{tabular} & $2007 / 09$ & 慈済基金に申し込んだ. & 漁業 & 漁業 & $\begin{array}{l}\text { 水が黄色く, } \\
\text { 用途が限られ } \\
\text { てしまう }\end{array}$ & • 慈済基金の住宅情報は中国系である親成から得た. \\
\hline 3 & 持家 & •アチェブサール県の親墄宅 & $2005 / 12$ & 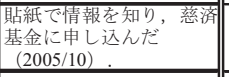 & & & $\begin{array}{l}\text { 井戸水が黄色 } \\
\text { いが, 水道氏 } \\
\text { は問題ない }\end{array}$ & $\begin{array}{l}\text { •被災したウレレに所有していた土地は, 被災後の道路拡張工 } \\
\text { 事に伴い政府が買い取った。 }\end{array}$ \\
\hline 4 & $\begin{array}{l}\text { ウレレ } \\
\text { 借家 }\end{array}$ & \begin{tabular}{|l|} 
仮設住宅入居までは入院していた \\
・慈済基金の仮設住宅 \\
$(2005 / 03-2005 / 12)$
\end{tabular} & $2005 / 12$ & $\begin{array}{l}\text { 仮設住宅で情報を入手し } \\
\text { 1回の面接を経て入居決 } \\
\text { 定. }\end{array}$ & & & 特に無し & $\begin{array}{l}\text { - 被災前の所有地は津波で掘削されてしまい, 失った. } \\
\text { •被災当時の近隣住民は同じ仮設住宅，恒久住宅に多く入居し } \\
\text { ている(おそらく } 100 \text { 世带ほど). }\end{array}$ \\
\hline 5 & 借家 & $\begin{array}{l}\text { • 慈済基金の仮設住宅に入居 } \\
\quad(2005 / 03-2005 / 12)\end{array}$ & $2005 / 12$ & $\begin{array}{l}\text { 仮設住宅で情報を得て申 } \\
\text { し込み. }\end{array}$ & \begin{tabular}{||l}
$\mid$ \\
$(3$ 輪タク \\
ジー)
\end{tabular} & $\begin{array}{l}\text { ベチャ } \\
(3 \text { 輪夕ク } \\
\text { ジー })\end{array}$ & $\begin{array}{l}\text { 井戸水が黄色 } \\
\text { W }\end{array}$ & 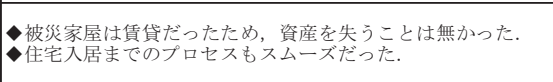 \\
\hline 6 & 借家 & \begin{tabular}{|l|} 
・被災後メダンに避難し，仮設住宅 \\
に入居 $(2005 / 05)$.
\end{tabular} & $2005 / 12$ & 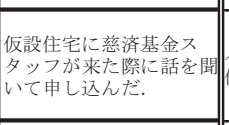 & 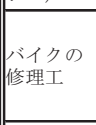 & $\begin{array}{l}\text { バイクの修理 } \\
\text { 工 } \\
\text { (被災後は } \\
\text { 2006年4月ま } \\
\text { で休業) } \\
\end{array}$ & 特に無し & $\begin{array}{l}\text { •息子が被災地に残っており，現在恒久住宅へ申し込んでいる } \\
\text { とこである. }\end{array}$ \\
\hline 7 & ウレレ & • 仮設住宅 & & $\begin{array}{l}\text { 仮設住宅に慈済基金天 } \\
\text { タッフが来た閔に話 } \\
\text { いて申し込んだ. }\end{array}$ & |無職 & 漁業 & \begin{tabular}{|l} 
水道水が少し \\
污い
\end{tabular} & $\begin{array}{l}\text { •被災した土地は津波で掘削されて現在は無くなっているが, } \\
\text { 土地に関しては政府からの支援は無い. }\end{array}$ \\
\hline 8 & ランディギン & $\begin{array}{l}\text { 大統領夫人が建設した仮設住宅 } \\
\text { (2006/09-2007/01) } \\
\text { •仮設住宅以前は親戚宅に居候. }\end{array}$ & $2007 / 01$ & $\begin{array}{l}\text { 2006年 } 12 \text { 月に入居の話を圭聞いて書類を提出し, 面| } \\
\text { 接を経て入居決定. }\end{array}$ & & & 水道 & $\begin{array}{l}\text { 場入居前は, 慈済基金以外の埂である恒宅への入居話もあったが, } \\
\text { 募しないでいた. }\end{array}$ \\
\hline 9 & 一借家 & $\begin{array}{l}\text { •病院（1ケ月入院）を経て, 親戚 } \\
\text { 宅を回っていた. }\end{array}$ & & & 役所 & 役所 & 特に無し & $\begin{array}{l}\text { •自分の土地を持っていなかったのでNGOらの支援を得て家 } \\
\text { 屋を再建することは出来なかった. } \\
\text { •仮設住宅も満員状態で入ることが出来なかった. }\end{array}$ \\
\hline 10 & $\mid \begin{array}{l}\text { カンンプンバン } \\
\text { 借家 }\end{array}$ & \begin{tabular}{|l|} 
被災後は治療のためにマレーシア \\
病院で2ケ月過ごした. \\
•ジェントの慈済基金が建てた仮設 \\
住宅に入居 $(2005 / 12)$.
\end{tabular} & $2005 / 12$ & & |菓子売り & 菓子売り & $\begin{array}{l}\text { 被災前のよう } \\
\text { に店を出して } \\
\text { 商売が出来な } \\
\text { いこと }\end{array}$ & $\begin{array}{l}\text {-ママーシアへの渡航費は家族が負担し, NGOからの支援は } \\
\text { 無かった. } \\
\text { 現在は店が無いので, 家で菓子を作りコーヒーショップに売 } \\
\text { り歩いて生計を建てている. }\end{array}$ \\
\hline 11 & 借家 リンケ & 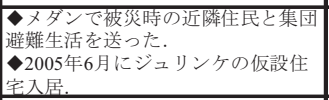 & $2007 / 06$ & & & & 特に無し & \\
\hline 12 & ランンプロスケッ & 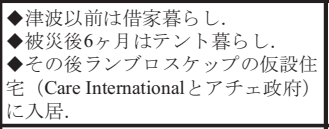 & $2007 / 06$ & $\begin{array}{l}\text { 仮設住宅入居時にBRRの } \\
\text { 抽選ん当選し入居が決 } \\
\text { 定. }\end{array}$ & 商売 & 商売 & $\begin{array}{l}\text { 井戸水が黄色 } \\
\text { 点 }\end{array}$ & 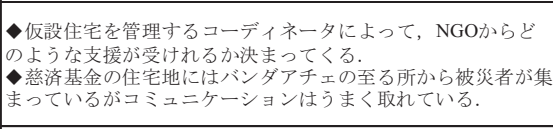 \\
\hline 13 & $\begin{array}{l}\text { カジュ(アチェブ } \\
\text { サール県) } \\
\text { 持家 }\end{array}$ & \begin{tabular}{|l|} 
•仮設住宅へ入居したかったが，空 \\
きが無く親戚宅を回っていた.
\end{tabular} & $2006 / 03$ & & 役所 & 役所 & 特に無し & 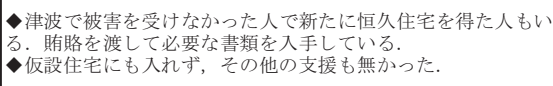 \\
\hline 14 & $\begin{array}{l}\text { プンゲブラン } \\
\text { カッッ } \\
\text { 借家 }\end{array}$ & $\begin{array}{l}\text { マタイーのテントで1年間過ご } \\
\text { L, その後親戚の家に移った. } \\
\text { 2006年7月に被災場所の仮設住宅 } \\
\text { (IOM) に入古. }\end{array}$ & $2007 / 07$ & $\begin{array}{l}\text { 被災当時の部落の長から } \\
\text { 情報を聞き募. }\end{array}$ & 無職 & $\begin{array}{l}\text { 無職 } \\
\text { (家族か.5の } \\
\text { 援助で生活) }\end{array}$ & 特に無し & \\
\hline 15 & $\begin{array}{l}\text { ウレレ } \\
\text { 持家 }\end{array}$ & $\begin{array}{l}\text { •マタイーのテントで1年過ごし, } \\
\text { 2006年1月にLhong Rayaの仮設住宅 } \\
\text { に入居. }\end{array}$ & $2007 / 05$ & $\begin{array}{l}\text { BRRへの申し込みはかなa } \\
\text { り早かったが, スタッフ } \\
\text { ともめたため人居が遅れ| } \\
\text { た. }\end{array}$ & |漁業 & 漁業 & 特に無し & 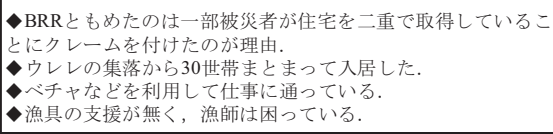 \\
\hline 16 & \begin{tabular}{|} 
メルドゥアティ \\
借家
\end{tabular} & •アチェブサール県の親戚宅 & $2007 / 05$ & $\begin{array}{l}\text { 新聞で入居情報を得て, } \\
\text { 慈済基金に直接申し込ん } \\
\text { だ. }(2006 / 11)\end{array}$ & \begin{tabular}{||l} 
\\
$(3$ 輪夕ク \\
シー)
\end{tabular} & $\begin{array}{l}\text { ベチャ } \\
(3 \text { 輪夕ク } \\
\text { シー) }\end{array}$ & 特に無し & •いくつかの世帯は慈済基金の同じ住宅地に入居している. \\
\hline
\end{tabular}


本研究では主に第 4 段階の「生活再建」に着目し, 恒久住宅にお ける生活上の問題点を明らかにすることとする. なお, 調查時 $(2008$ 年 3 月時点）において, 仮設住宅に住むなど, 恒久住宅に未入居の 場合は，その時点までの経緯と生活上の問題点をヒアリングにより 整理した，本章では慈済基金住宅地，および被災者がなお居住して いる沿岸被災地にわけて整理する，そして，次章ではこれらのヒア リング結果よりバンダアチェ市における住宅再建プロセスの構造化 を図り，第 1 段階から第 4 段階全体の過程と各段階における問題点 の整理および考察を行う。

\section{(2) 慈済基金住宅地のヒアリング結果}

ここでは慈済基金住宅地でのヒアリングより明らかになったこと について考察する。まず, ヒアリングにより得られた被災者の復興 の経緯などを表 3 のようにまとめた．そして，この結果に基づき， (1)入居までの経緯, (2)現在の居住環境と生活, そして(3)今後の展望, という3つの項目に分けて整理する.

\section{(1) 入居までの経緯}

住宅入居に関する情報の入手経路については, 住民へのヒアリン

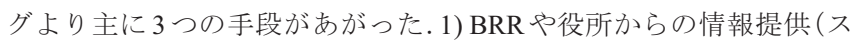
タッフ, 貼紙, 新聞記事を通じて)，2）知人からの情報入手，3）慈 済基金（仮設住宅入居時）である。いずれの場合も，住宅入居の情 報を得た後, 慈済基金スタッフと面接し, BRR による抽選を経て, 入居していた注 2 . しかし面接の夕か, 抽選まで行うかは被災者の入 居申し込夕時期や，対応するスタッフによって異なっており。入居 までのプロセスが明確に定められていたとはいえない. そして, ヒ アリング対象の 16 件中，10 件は被災以前の住宅が借家であり，被 災家屋が持家か借家かによって支援方法が分けられているわけでは ない.

抽選の結果, 恒久住宅に入居出来なかった被災者や, BRR などの 政府機関からの被災者支援情報を得ていない被災者の多くは, いま だに仮設住宅や親戚宅での生活を余儀なくされている.

\section{(2) 現在の居住環境と生活}

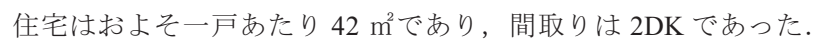
被災者へのヒアリングからは, 飲料水の問題を除き, 住宅そのもの への不満はそれほどないといったことが訊かれた。

一方で, この住宅地に限らず恒久住宅の二重取得は一つの大きな 問題としてあげられ, 慈済基金の住宅地だけでも 68 戸が二重取得の 疑いがもたれているということであった。 前述したように, 2008 年 1 月時点で仮設住宅の居住者が 2,000 人以上おり, 恒久住宅への入 居を希望しても入れない被災者がいるというのが現状である.した がって，住宅の二重取得は厳しく取り締まるべきである。慈済基金 の話によると, 二重取得が発覚した場合には強制退去させるとのこ とであったが，津波による公的書類の紛失や入居申請のプロセスが 画一化されていないことにより監視が行き届いていないのが現状で ある。

職業に関しては, 漁業, ベチャ（タクシー）の運転手, 警察官, バイクの修理工など様々であった. ウレレから移転してきた 30 世帯 に関しては, 全て漁業従事者であり, 住宅近くからでるバスを利用 するか, バイクで海まで容易に行けるため, 仕事上の問題は訊かれ なかった。むしろ, 内陸部で安全に住めることに満足しているとい
う意見が多く訊かれた。

\section{(3) 今後の展望}

入居者はごみ収集代として毎月 5,000 ルピア注3) を支払うものの, 住宅の賃貸料などの支払いは必要なく，かつ住人に住宅の所有権が 与えられている。ここでは，被災者は自ら移転しない限り，同住宅 地に生活の基盤を築いていくが，住宅の維持管理は政府が行うこと になっている注2). 敷地内には小中学校や, 住民の集会所などが設置 されている.そのため, バンダアチェ市の複数個所から移転してき た被災者間で新しいコミュニティ意識も生まれ，隣人関係も概福 好である。また，慈済基金の住宅地は他の住宅地に比べ住宅の完成 度が高いため, 入居することが出来た被災者からは大きな不満は訊 かれなかった。

\section{(3)沿岸被災地のヒアリング結果}

BAPPENAS の復興計画「Blue Print」をもとにJICA が作成したマ スタープランでは, 海岸から $2 \mathrm{~km}$ 以内は建設規制ゾーンとされてお り，被災家屋の再建が規制されている。しかしながら，前節の慈済 基金による住宅地のように内陸部に定住地が建設されている一方で, 沿岸被災地では NGO の支援により住宅の再建が進められている. そこで, 慈済基金住宅地でのヒアリングをもとに, 入居者の主な被 災前居住地である沿岸部のウレレ, ダヤグランパン, ランプロ, ダ ヤラヤの 4 地区（図 2）においてもヒアリング調査を行った.

本節では, ヒアリング結果をもとに表 4 のようにまとめたうえで, 前節と同様に, (1)入居までの経緯, (2)現在の居住環境と生活, そし て(3)今後の展望, について整理する.

\section{(1) 入居までの経緯}

被災地で再建した被災者からは，仕事が漁業であるため，海から 離れると仕事が成り立たないといった意見が聞かれた。そのため， 被災以前に住んでいた場所を離れないですむように，NGO や BRR が建設した恒久住宅への入居を希望した人が多かった。入居の手続 きとしては，仮設住宅入居時に NGO から住宅建設の話を聞き，応 募した場合や, 村全体の住宅再建を赤十字社が取りまとめ村民の住 宅再建を取り計らった事例が見られた。いずれも，仮設住宅入居時 に恒久住宅支援の情報を入手していることがわかった．

また, 入居の時期はウレレが 2006 年 6 月と最も早く, ダヤグラン パンとランプロでは 2007 年 2 月, 3 月であり, ダヤラヤの被災者は 依然として仮設住宅での生活を続けている状態であった。

\section{(2) 現在の居住環境と生活}

海に面し, 津波により沿岸の土地が掘削されたウレレでは, 漁業 従事者が多いということもあり，BRR，Care International（NGO）， そして UPLINK（NGO）がそれぞれ恒久住宅を建設し，入居者には 慈済基金の住宅と同様に，住宅とその所有権が与えられた。ヒアリ ングを行った被災者の多くが，津波以前に家を所有していた。 UPLINK により建設された住宅では，1階部分がピロティとなって おり満潮時の高潮備えた仕様となっている. 一方, BRRにより建設 された住宅は平屋であり高潮の影響を度々受けるため, 一度入居し た被災者が他に移ってしまったケースが多くあるということであっ た（写真 2)。また，この地域では住民の多くが漁業従事者であるに も関わらず, NGOからボートや漁網の支援は少なく, まれにボート などの支援があっても地域の漁法に合わないために使用できない， 
表 4 沿岸部で再建を進める被災者の住宅再建までの経緯および居住環境に関する問題点

\begin{tabular}{|c|c|c|c|c|c|c|c|c|}
\hline \multirow{2}{*}{ No. } & \multirow{2}{*}{$\begin{array}{l}\text { 被災場所 } \\
\text { 住宅の所有形態 }\end{array}$} & \multirow{2}{*}{ 恒久住宅入居までの生活 } & \multirow{2}{*}{\begin{tabular}{|l|l|} 
恒久住宅 \\
入居時期 \\
\end{tabular}} & \multirow{2}{*}{ 恒久住宅への応募方法 } & \multicolumn{2}{|r|}{ 仕事 } & \multirow{2}{*}{\begin{tabular}{|l} 
住宅・設備に \\
関する問題
\end{tabular}} & \multirow{2}{*}{ 備考 } \\
\hline & & & & & 被災前 & 被災後 & & \\
\hline 17 & ダヤラヤ & $\begin{array}{l}\text { •2008年2月末時点で仮設住宅に居 } \\
\text { 住（ドナー: GTZ）. }\end{array}$ & $\begin{array}{r}2008 / 03 \\
\text { 予定 }\end{array}$ & & |主に漁師 & 主に漁師 & & 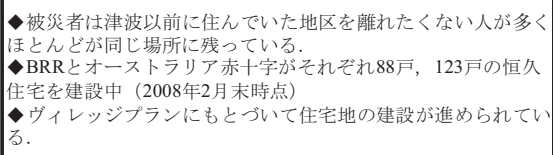 \\
\hline 18 & $\mid \begin{array}{l}\text { ウレレ } \\
\text { 持家 }\end{array}$ & \begin{tabular}{|l|} 
•被災直後にマタイーに移り, \\
UPLINKが建設した仮設住宅に2006 \\
年6月まで生活していた.
\end{tabular} & $2006 / 06$ & \begin{tabular}{|l||} 
仮設住宅がUPLINKのも \\
のであったため, 同じ \\
UPLINKが建てる恒久住 \\
宅の話を聞いて申し込ん \\
だ.
\end{tabular} & $\mid$\begin{tabular}{||l}
$\mid$ 地地区の \\
$75 \%)$
\end{tabular} & 漁師 & $\begin{array}{l}\text { ピロティの有 } \\
\text { 無 }\end{array}$ & 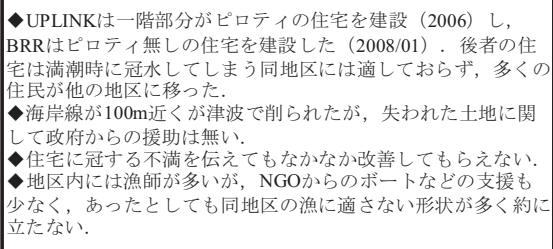 \\
\hline 19 & $\begin{array}{l}\text { F゙ヤグランパン } \\
\text { 持家 }\end{array}$ & $\begin{array}{l}\text { •内陸の避難所を経て, 仮設住宅で } \\
\text { 生活 (2005 }\end{array}$ & $2007 / 03$ & $\begin{array}{l}\text { 仮設住宅にWorld Vision } \\
\text { のスタッフが来た際に申 } \\
\text { し込んだ. }\end{array}$ & 商店 & 商店 & & 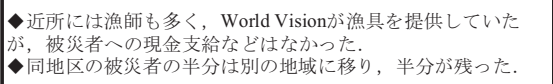 \\
\hline 20 & $\mid \begin{array}{l}\text { ランプロ } \\
\text { 持家 }\end{array}$ & \begin{tabular}{|l|} 
•フランス, インドネンア赤十字の \\
仮設住宅 (2005/12まで). \\
•恒久住宅入居は2007年2月
\end{tabular} & $2007 / 02$ & \begin{tabular}{|l||} 
村にNGOが複数来て, \\
住宅の建設が決定し, 村 \\
長が入居の取りまと \\
(振り分け)をした.
\end{tabular} & |漁師 & 漁師 & & 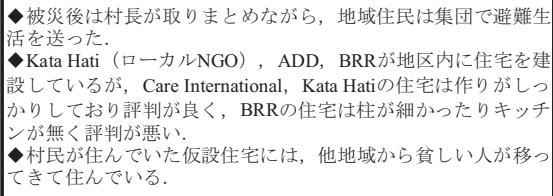 \\
\hline
\end{tabular}

という声も訊かれた。

\section{(3) 今後の展望}

被災地で再建を進めている被災者の多くは, 住み慣れた土地への 愛着や仕事上の関係で住み続けているケースがほとんどで，ピロテ イを持つ住宅に入居できている被災者は，このまま被災地に残り生 活を続けたいということであった。しかしヒアリングの結果を踏ま えると, BRRの恒久住宅のように住宅の仕様に問題がある場合には, 今後も移転する人が増える可能性があると言える。したがって, 迅 速に恒久住宅の建設を進める事は重要であるが，入居した被苂者に とって恒久的な住宅になるように, 住宅建設地の選定や住宅の仕様 には特段の配慮が求められる.

\section{5. 住宅再建プロセスの構造化}

4 で整理した居住環境に関する問題は，恒久住宅のあり方，大規 模災害時特有の住民の集団移転を考える上で重要なものである．上 アリング調查により居住環境の問題以外にも, 被災者の再建過程に 関して, 恒久住宅の入居までの経緯や時期に違いが生じていること がわかった. そこで, 本章では先に定義した四つの各段階をさらに 詳細に整理し, $\mathrm{Murao}^{7)} の$ 研究で提示された「地震後の復興過程の構 造」を参考に, バンダアチェ市における再建過程を構造化すること で被災者の再建プロセスに差異が生じる状況について考察を行う。 これらのインタビュー, 質問表調查など方法は, 佐藤 ${ }^{14)}$ が示寸よう に現場において全体的な方向をとらえるうえで有用である.

\section{(1) 再建過程における分岐路の抽出}

被害の大きさや, 家族構成, 経済力, そして住んでいる地域や村 のコミュニティの状況などによって被災者の再建プロセスは一つひ とつ異なる. しかし, 復興の各段階ではどの被災者にも共通する分 岐点が存在し, その選択結果によって被災者の再建プロセスに一定 の方向性が位置づけられることとなる。本研究では, ヒアリングを
もとにそのような再建過程において重要と思われる分岐点を抽出， 設定した。 そして, 被災者の住宅被災からその再建に至るプロセス を図 5 のように構造化した。図中の項目は, 再建過程における分岐 点 $(\diamond)$ と, 各復興段階において被災者がとる過程（口）を示して いる。図は建物の被災の有無を始点とし，生存している被災者の生 活再建がどのような経過をたどるかを示している。

\section{（2）選択肢の違いによる再建への影響}

ヒアリング調查を整理した結果，恒久住宅への入居時期が遅れた 理由としていくつかの共通点が見られた。まず，第 2 段階の Q:2-1 「仮設住宅への入居」時点において, 仮設住宅に入らなかったケー スである，仮設住宅に入らず，親戚宅をまわり避難生活を送ること で住宅再建支援に関する公的情報の入手が遅れ，結果として恒久住 宅への入居が遅れたケースが数多く見受けられた（図 6).また，同 時期に情報を入手していても，慈済基金の仮設住宅入居者が優先的 に慈済基金スタッフとの面談を受けて入居が決定するなど，入居時 期にずれが生じていた。被災者の入居手続きが確立されているとは いえず，大きな課題となっている.

次に，移転する場合と被苂地で住宅再建した場合（Q:3-1）でも住 宅入居後の被災者の生活に大きな違いが生じているケースが見られ た，慈済基金住宅地入居者の場合，水の問題を除き，居住環境に関 する不満は訊かれなかった。一方で，ドナーが沿岸被災地に建設し た恒久住宅に入居した被災者からは，住宅が満潮時に浸水するとい った, 住宅の仕様に関する不満が訊かれた（図 5:3-2, 4-1, 写真 2). 大規模な住宅地を建設する移転型の住宅再建では, BRR とドナーに よる計画が綿密に進められるものの, 被災地での住宅再建では地域 に求められる居住環境への考慮が十分行われているとは言い難く, 地域ごとに求められている住宅の機能（沿岸部住宅におけるピロテ イの設置など）といった，ニーズの把握が重要であるといえる. 
6. まとめ

本稿ではバンダアチェ市における生活再建プロセスを対象として, 現地調查をもとに復興過程を構造的に示し, 被災者の再建プロセス を構造化した。また，ヒアリング調查より被災から 3 年経過時点の 被災地の現状, および住宅再建における問題点を整理した. 以下, 本研究で明らかになったことをまとめる。

\section{(1) 再建過程おける異なる選択肢}

被災後の避難生活を仮設住宅で過ごすか，親戚宅を回るか，ま たは，仕事上の都合や土地への愛着から被災地に残るか，津波を 恐れ内陸部にある恒久住宅地一の入居を希望するかなど, 再建過 程における選択肢の違いにより, 恒久住宅への入居時期が遅れる などの違いがみられた。

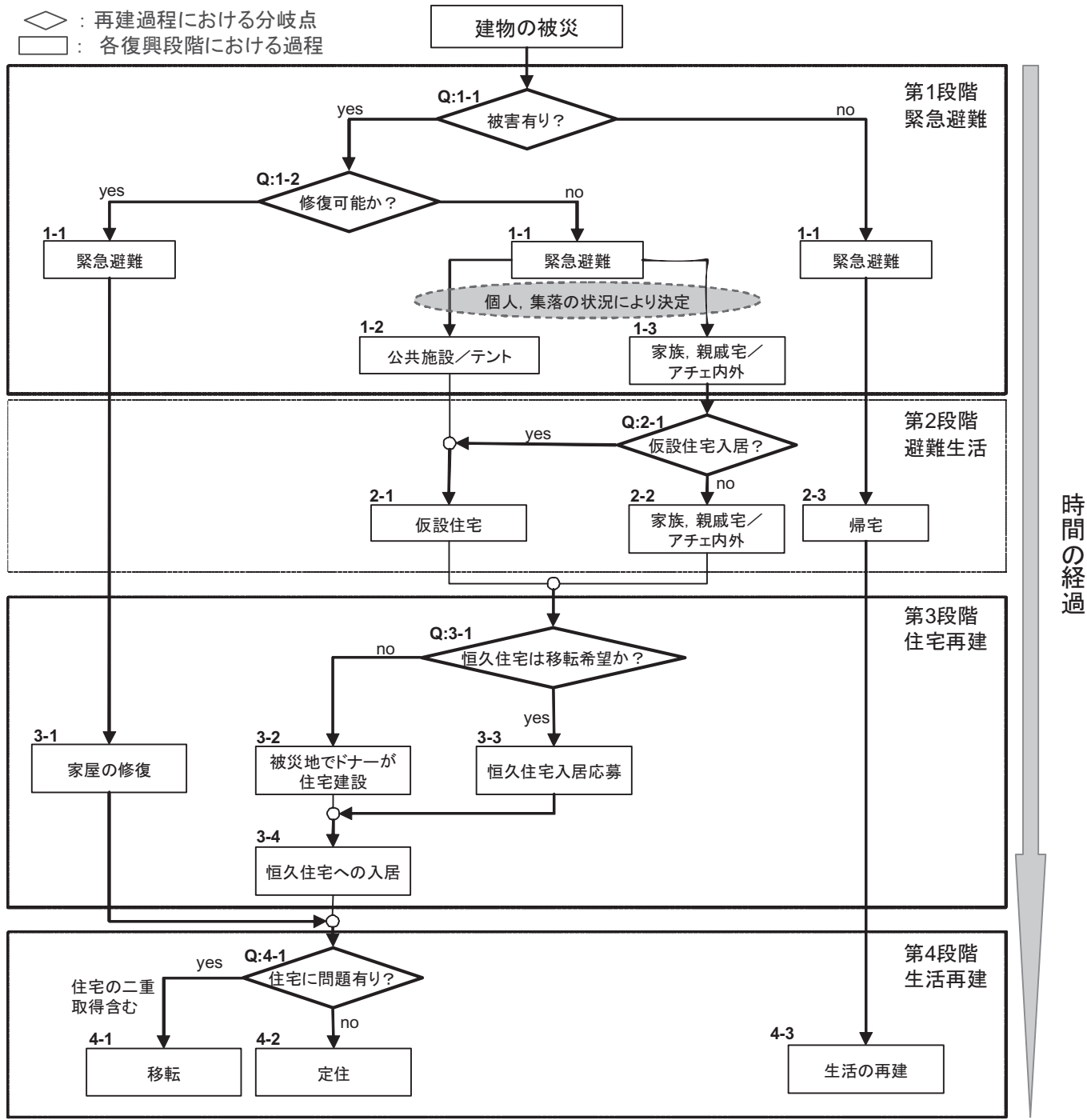

図 5 住宅の被災から再建までの流れ

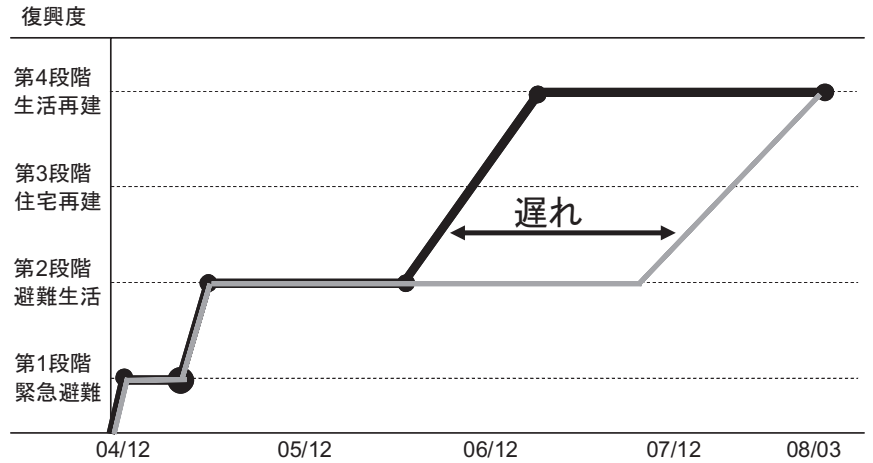

図 6 バンダアチェにおける復興過程

(ヒアリングより得られた最速と最遅のケース)

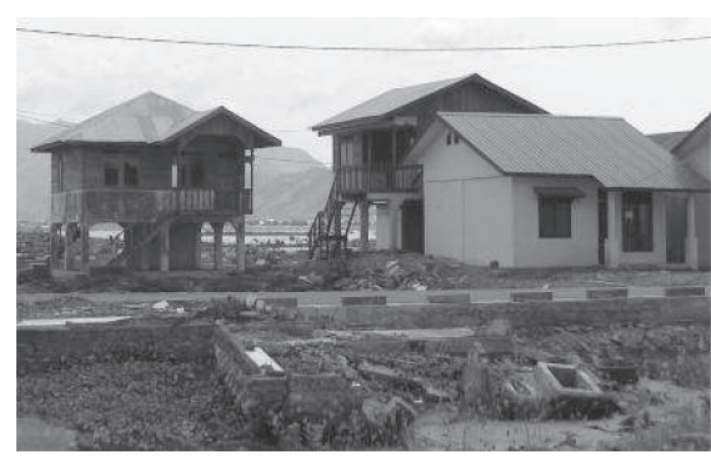

写真 2 UPLINKの住宅 (奥) と BRR の住宅 (手前) 


\section{(2) ドナーの違いによる再建過程の差異}

慈済基金の住宅に入居できなかった被荻者や，ドナーの支援に より住宅が再建された沿岸の被災地では, 被災者が入居しないま まの住宅，または入居してもすぐに移転してしまうケースがあっ た.

\section{(3) 被災者のニーズを把握した支援のあり方}

慈済基金の住宅の質が比較的良く，そして住宅とともに小中学 校，や集会所などの施設が伴うことで被災者が新しく生活を送る 上での基盤が整っているため, 概ね良好な復興の過程にある様子 が同えた。一方で，(2)に示した住宅の問題や，漁業関係者への適 切な漁具の支援が行われなかったことなど，被災者支援のあり方 に関して課題が明らかになった。一方的な支援ではなく，被災者 のニーズを把握した上で支援を進めることが重要である.

\section{(4) 再建事業の管理のあり方に関する課題}

被災者への情報伝達が遅れたことにより住宅への入居が遅れて いるケースが多く見られた。災害後の混乱時に全ての被災者にど れだけ迅速，かつ正確に支援情報を伝達できるかどうかが重要で あることが明らかになったといえる。また，5（2）に挙げたように 恒久住宅の入居に関しては，入居手続きは画一化されているとは いえず，支援を行う側の課題が明らかになった。一方で，慈済基 金の住宅で二重取得が発生するなど, 管理する側の問題とともに, 支援を受ける立場である被災者のモラルに関する問題も明らかに なった.

このようにバンダアチェ市の復興過程における課題が明らかにな った.被災地で迅速かつ質の高い被災者支援をするためには,まず, 行政之 NGO などの支援団体間で，被災者の情報を正確に把握，管 理し, 被災者向けの情報提供手段や支援プロセスを確立することが 重要であると考えられる。また，恒久住宅入居にあたっては，住宅 の二重取得を防ぐためにも既入居者と未入居者をデータベース作成 などにより管理する事が不可欠である。

そして, ウレレの事例にみられた恒久住宅の転出問題などを防ぐ ためにも, NGO の支援で住宅を提供する事業は, 迅速かつ, 被災地 や被災者の実態を考慮したうえで, 適切な場所に適切な住宅を建設 する必要があるといえる。

復興事業は今後も継続されるが，BRR は 2009 年 3 月で解散し， 中央政府が事業を統括することとなっている．組織の改変を含め今 後の復興事業に着目し動向を追っていく必要がある。また, 本研究 で対象としたインドネシア・バンダアチェ市と, スリランカ, タイ の津波被災地の復興過程では，支援団体のプロジェクトへの関わり 方や被災者の直接支援の有無などいくつかの違いが見られる。これ ら被災地の復興過程や支援団体，政府機関の再建事業への関わり方 の差異を比較することは，今後起こりうる大規模災害時の復興施策 を考える上で重要である。今後は各被災地における復興の経過を追 っていくことと合わせて，各国の復興過程の比較に取り組んでいき たい.
謝辞

本稿は，「平成 18 年度文部科学省振興調整費（我が国の国際的リ ーダーシップの確保）スマトラ型巨大地震・津波被害の軽減策 地 域特性を考慮した防災都市再開発計画・都市復興計画の研究と提案 (研究代表者: 筑波大学村尾修)」の一環として実施した調查に基づ く成果報告である. 通訳として調查に協力して頂いた Rivadsyah氏，

Sarah 氏に対し記して敬意を表す次第である.

参考文献

1) BRR : Aceh and Nias Two Years After the Tsunami 2006 Progress Report, pp27-28, 2006

2) 岡崎健二, 楢府龍雄 : アチェにおける住宅再建の実態, 日本建築学会計 画系論文集 No.619，pp257-262，2007.9

3) 前田昌弘, 中川雄輔, 山田協太，布野修司：インド洋スマトラ島沖地震 津波後のスリランカ南西沿岸居住地における復興の実態と問題点に関す る考察 一平常時の居住環境との連続性に着目して一, 日本建築学会計画 系論文集 No.614, pp183-190, 2007.4

4）佐藤仁：スマトラ沖地震による津波災害の教訓と生活復興への方策 タイの事例一, 地域安全学会論文集 No.7, pp433-442, 2005

5) 山本直彦, 牧紀男：バンダアチェ市（インドネシア）におけるスマトラ 沖地震後の復興住宅の初期供給プロセス, 日本建築学会大会学術講演梗 概集 F-1，pp1121-1122，2006

6) 池田浩敬，中林一樹：日本・トルコ・台湾における持ち家世帯向けの住 宅再建・補修への経済的支援策の比較 - 日本・トルコ・台湾, 震災復 興過程の国際比較研究 その 9 -, 日本建築学会大会学術講演梗概集 F-1 pp461-462, 2003

7) Murao, O.: Structure of Post-earthquake Recovery Process after the 1999 Chi-Chi Earthquake -A Case Study of Chi-Chi, Proceedings of the International Symposium on City Planning, pp.164-175, Taipei, Taiwan, 2006

8) 仲里英晃，村尾修：2004 年スマトラ沖津波後のスリランカにおける恒久 住宅建設過程の地域間比較，都市計画論文集 No.41-3，pp689-694，2006

9) 仲里英晃, 村尾修, 杉安和也 : 2008 年 3 月時点のバンダアチェにおける 恒久住宅の居住環境，都市計画報告集 No.7，pp27-30，2008

10) 杉安和也, 村尾修, 仲里英晃 : 2004 年インド洋津波後のインドネシア, タイ，スリランカにおける復興マスタープランの比較，都市計画報告集 No.7, 2008

11) BRR : Laying Down the Fundation for a Better Future: Six-monthly Report of the Executing Agency for the Rehabilitation and Reconstruction of Aceh and Nias, pp75-76, 2005

12）梶秀樹，大槻和史，高梨義也，後祐美：文部科学省 2006 年度学術フロン ティア事業 デジタルアジア構築と運用による地域戦略構想のための融 合研究 デジタルアジア・コミュニケーションウェア・プロジェクト, 途 上国大都市の災害脆弱性分析一北スマトラ沖地震津波災害における国際 復興支援一, pp22-23，2006

13) BRR : QUICT STAT per Januari， 2008

14）佐藤郁哉：フィールドワークの技法 問いを育てる，仮設をきたえる， 新曜社, 2002

注

注1）インドネシアの行政区画は 33 の州（Provinsi）が最上位の行政単位であ り，その下に県（kabupaten）または市（kota）の District，そしてさらに 地域（Sub-district），(Kecamatan）が位置づけられる。バンダアチェ市 （Banda Aceh）はアチェ州（Nanggroe Aceh Darussalam）の州都である.

注2）慈済基金住宅地で行った慈済基金スタッフへのヒアリングより

注3） 2008 年 5 月 28 日現在， 1 インドネシアルピア $=0.01$ 円である.

（2008年 7 月10日原稿受理，2009年 2 月12日採用決定） 